\title{
Small-Scale Renewable Energy in The Next Century Market Hydro Plants - State of The Art and Applications
}

\author{
C.Dragu ${ }^{1}$, J.Soens ${ }^{1}$ and R. Belmans ${ }^{1}$ \\ ${ }^{1}$ K.U.Leuven, ELECTA, Energy Institute, Kasteelpark Arenberg 10, B-3001 Leuven - Belgium \\ Phone: +32-16-32 10 31, Fax: +32-16-32 19 85, E-mail: catalin.dragu@esat.kuleuven.ac.be
}

\begin{abstract}
In the near future, demand for electricity is expected to increase more rapidly than demand for other forms of energy. After reviewing the tendencies of the energy market for the next century, Small and Micro-Power Systems are presented. The decision to build a hydro plant must be based on studies about the site potential, economical potential, environmental impact and technological aspects. This paper presents the literature study of the advantages and drawbacks of Small and Micro Hydro Plants. In the last years, special attention was paid to the wind and solar power. A comparison with other renewable is therefore very important.
\end{abstract}

Two principal economic characteristics of hydropower are high initial and low operating costs. From studied literature an easy algorithm is proposed, in order to assure the maximum efficiency for minimum costs of a site. With minimum electrical-mechanical knowledge, the owner of the site can design a small hydro plant optimizing the total price.

An economical and technical review of the essential components (civil works and mechanical and electrical equipment) of a small hydropower system is made and projected on two different sites in Flanders.

\section{Key words}

Small and Micro hydro plants, site potential, environmental and technological aspects, turbines, electricity market liberalization, wind and solar plants.

\section{Introduction}

The last decade has shown an accelerated increase of demand for resources in all the economical sectors. Among these, the demand for electricity knows the highest rate of growing. In this global environment, it is expected that the position of renewable technologies to become more and more important. This is doubled by new European and national legislation in the domain of liberalization of energy market.

The small-scale renewable generation may be the most cost-effective way to bring electricity to remote villages that are not near transmission lines. Less centralized power technologies, such as natural gas units and smallscale renewable energy, can benefit from tighter environmental demands.

Hydro electric energy is worldwide responsible for some $2600 \mathrm{TWh}$ of electricity output per year, which means about $20 \%$ of the world's entire electricity demand.

\section{Energy Market in the New Millennium}

The challenge of the new millennium is to assure a durable global economic growth together with the respect of new international environmental regulation.

In the industrialized world, the economic growth and growing electrical applications as computers, communication technologies, and other electronics for home and business use, increase the electrical energy demand. This demand growth is tempered by increases in energy efficiency, by more severe regulation and by technological innovations.

The liberalization of the European electricity market, the environmental concerns, especially those related to $\mathrm{CO}_{2}-$ emission, and the sensitivity of the public opinion are among the main factors which make that the renewable power generation, mainly in the form of hydropower, becomes very competitive with the classical form of producing energy, particularly the coal and nuclear energy.

A clear tendency of increasing hydropower generation is seen specially in the industrialized countries (such as Canada or Japan), as well in the in the developing world, where small-scale renewable generation may be the most cost-effective way to bring electricity to remote villages that are not near transmission system.

Total electricity generation in Western Europe is projected to grow from $2300 \mathrm{GWh}$ in 1995 to $3800 \mathrm{GWh}$ in 2015. In Eastern Europe and in the Former Soviet Union, renewable generation (primarily hydropower) is expected to rise as a percentage of generation.

\section{Alternative Technologies}

The major purpose for small generation plants is to provide small amounts of electric power in isolated areas, where the connection to the electrical grid is hard or impossible due to the location. There is a multiple choice of generation plant, each one having its own advantages and drawbacks, which depend mainly of the specific characteristics of the location. Hence, a list of such advantages and drawbacks is hard to make, and giving the best advice among all possibilities even harder. The main candidates in a tight competition with hydro energy are diesel and gasoline-engine generators, wind-electric generation, and photovoltaic cells. The main features of selection are the starting and long-term cost, reliability, 
ecological and environmental legislation and the accessibility to the resources as water, wind, gas, etc.

\section{A. Diesel and Gasoline-engine Generators}

The main drawback of this type of generators is the longterm cost, particularly the dependences of the fuel quality and the fuel market price. The start cost of an diesel generating system is not high, depending of the size, (larger systems costing less per kilowatt). Conform to [4], the long-term price of electricity generated for $1 \mathrm{~kW}$ unit running continuously for a year is about $€ 1,750$.

This type of generator is very suitable for the highly isolated villages where there is no good "location" for wind, hydro or solar generation.

\section{B. Wind-electric Generation}

The wind-electric generators consist of a wind turbine that drives a generator to charge batteries or provide electric power directly. The cost per kWh can vary, depending on the site location. At the $160 \mathrm{MW}$ offshore wind farm of Horns Rev, prices as low as $5 \mathrm{c} / \mathrm{kWh}$ are noted.

The price of a wind-electric generator system costs $50 \%$ more than its equivalent diesel and gasoline-engine generator. Depending on the weather conditions, a windelectric generator unit has only an annual energy yield of $20 \%-40 \%$ of its installed power x $8760 \mathrm{~h}$.

\section{Photovoltaic cells}

The idea to transform the solar power into energy has been initially developed by NASA in order to supply electricity to the communication and military satellites in space. If at the beginning this technology seemed to be accessible only to the reach industrialized countries, in the near future it seems to be the first choice of developing countries. Even if today the price of a solar system is higher than any other renewable generation system, the mass production doubled by a high rate of growing investments in this field will make this price acceptable for most applications.

The technology consists in the use of solar cells, inverters and special control devices in order to transform the solar power into energy. Small power devices can directly use the electrical energy produced or it can be stored in batteries. This kind of generators is even more sensitive to weather conditions and to the natural cycle day-night or seasons, the actual amount of energy generated per year being only about 10 to 20 percent of the maximum. An economical advantage is that the photovoltaic generators are most advantageous where very small amounts of power are needed. As a conclusion, for little power they can provide the best choice.

\section{Why Hydro Power Systems?}

The definition of micro hydropower varies in different countries and can even include systems with a capacity of a few megawatts. One of the many definitions for micro hydropower is: hydro systems up till a rated capacity of approximately $300 \mathrm{~kW}$ capacity. The limit is set to 300 $\mathrm{kW}$ because this is about the maximum size for most stand alone hydro systems not connected to the grid, and suitable for "run-of-the-river" installations.

Definitions of small, mini, and micro hydro plants found in literature (Source: Moreire, J.R. \& Poole, A.D. (1993) Hydropower and its constraints, In: Johansson T.B. et al, (1993) Renewable energy : sources for fuels and electricity (ISBN 1-85383-155-7) are presented in Table I:

TABLE I. - Definitions of micro, mini and small hydro plants

\begin{tabular}{|l|l|l|l|}
\hline Country & $\begin{array}{l}\text { micro } \\
\text { (kilowatts) }\end{array}$ & $\begin{array}{l}\text { mini } \\
\text { (kilowatts) }\end{array}$ & $\begin{array}{l}\text { small } \\
\text { (megawatts) }\end{array}$ \\
\hline United States & $<100$ & $100-1000$ & $1-30$ \\
United States & $<100$ & $100-1000$ & - \\
China & - & $<500$ & $0.5-25$ \\
Ussr & $<100$ & - & $0.1-30$ \\
France & $5-5000$ & - & - \\
India & $<100$ & $101-1000$ & $1-15$ \\
Brazil & $<100$ & $100-1000$ & $1-30$ \\
Various & $<100$ & $<1000$ & $<10$ \\
\hline
\end{tabular}

At present there is no precise definition of "Microhydro". Qualitatively, micro-hydro generation implies a localized, rural power system without extensive transmission lines or voltage transformation. Microhydro also implies a 'run of river' system in which no attempt is made to impound or store water with a dam or earth works, so the system is subject to seasonal fluctuations of river flow and can never use more water than the full flow of the river at any given time.

Hydro energy is widely accepted as a clean and environmentally friendly energy, but it is not always the case. Besides the ecological potential, a comparison of the yield factors of types of energy plant suggests that hydropower remains the most valuable form of energy. This is presented more explicitly in Table II. By definition the yield factor is the ratio of the quantity of energy produced by an installation during its lifetime and the energy required manufacturing the installation, its operation and disposal including secondary energy.

TABLE II. Yield factor for power plants

\begin{tabular}{|l|l|}
\hline Plant & Yield Factor \\
\hline Small hydro & $80-100$ \\
Large hydro & $100-200$ \\
Photovoltaics & $3-5$ \\
Solar (thermal) & $20-50$ \\
Wind power & $10-30$ \\
\hline
\end{tabular}




\section{A. Advantages of Small Hydro Plants}

Small hydro plants are reliable and within the limits of the water resources available, can be tailored to the needs of the end use market. The facilities have a long life. As a rule of thumb, dams and control works will perform for a century or more with little maintenance.

The civil works are simple and do not need elaborate construction works in reinforced concrete, no expensive power house and highly optimized electromechanical equipment. These also do not need high safety standards in construction works as even the rupture of a small dam would not usually threaten the human life. Because of all these simplicities they can be planned and built in less time and their cost can be cut perhaps by a factor of two or more. Plants can be designed and built within one or two years' time. Licensing requirements are minimal, equipment is readily available, and construction procedures are well known.

A small hydro plant is characterized by reliability and flexibility of operation, including fast start-up and shutdown in response to rapid demand changes. In any large electrical system, the small hydro technology becomes a valuable alternative increasing overall economy, efficiency and reliability.

There is no need for a long transmission lines because output is consumed near the source and the technology is easy to adopt for producing electricity, high performing electrical equipment (alternator, control circuit, battery storage, regulator) can be easily found in the market. The modern turbine efficiency is up to $90 \%$.

Plants require some type of water control, up to and including full regulation of watershed discharge. They are thus an important element in the multipurpose utilization of water resources and can reduce potential flood damage. Where storage facilities are involved, floodwaters are retained and can be better directed to agricultural production, river regulation, improved navigation, fish and wildlife protection, recreation, municipal use and better control of waste water.

The possibility of retrofits and additional turbines and generators makes the upgrading of existing installations attractive.

\section{B. Drawbacks of Small Hydro Plants}

Hydro systems, unlike solar components for example do require some maintenance. Besides the high capital costs, the primary drawback of hydroelectric is its environmental effects. Hydroelectric sites create several problems for fish. The water inlet must be cleaned regularly, especially during fall leaf drop and spring runoff.

Dams present a migratory barrier that can effect the free movement of fish species and their reproduction cycle. The rotation of the turbines can kill fishes, especially young fishes swimming downstream. Spilling of water over spillways can result in supersaturating of the water with gases from the air. The gas bubbles, absorbed into fish tissue, may cause damage and ultimately kill the fish. The existence of the reservoirs can make the water becoming stratified, with warmer water collecting at the surface and cooler water lying at the bottom. In this way, the cold water is isolated from aeration and it loses its oxygen. Many species of fish cannot live in such environment due to the low oxygen content and temperature.

Tree clearing from the development of hydroelectric dams can result in soil erosion and landslides, also causing a build-up of sediments that clog up streams.

\section{Building a Small Hydro Plant}

Small, decentralized hydropower in development situations is clearly feasible. Due to transportation, material and financial difficulties of larger hydropower installations, small-scale hydropower installations are very desirable. In order to calculate the potential of a specific site, some information on the availability of power must be obtained. Information on elevation differences, amounts of water available, and construction feasibility also must be obtained.

\section{A. Site potential}

Total installed capacity world-wide of small hydropower facilities by the late 1980 s was $23,5 \mathrm{GW}, 38$ percent of which was generated in China. As of the beginning of the 1990s, international surveys on small-scale hydropower facilities (with capacities below $10 \mathrm{MW}$ ) found plants are currently under construction or are being planned in 100 countries. To take advantage of hydro power the water source must provide both volume and pressure (otherwise known as head).

The amount of power produced by a hydro plant will depend on the head (height water falls), the water flow (GPM) and the efficiency of the hydro turbine. These turbines provide DC power in either 12, 24 or 48 volts to charge a battery bank that, used in conjunction with an inverter, will provide $\mathrm{AC}$ voltage to a residential customer.

To determine the power that can be produced at one site the flow and the head are needed to know. The best sites have a reliable water supply year-round and a large vertical drop in a short distance. The theoretical total amount of power available at the site $P_{t h}$ is related of the rate of flow of water through the pipe $F$ and the head $H$ by the relation:

$$
P_{t h}[W]=F[\mathrm{~kg} / \mathrm{s}] \times H[\mathrm{~m}] \times 9,807[\mathrm{~N} / \mathrm{kg}]
$$

The efficiency of the turbines and generators depending of the manufacture is about 0.85 , so the amount of electric power $P_{\text {real }}$ actually delivered by the hydro site is lower than the theoretical. 
$P_{\text {real }}=P_{\text {th }} \times \eta_{\text {turbine }} \times \eta_{\text {generator }} \times \eta_{\text {el }- \text { system }}$

For pumps used as turbines, the efficiency is from 0.6 to 0.8 , and for locally built cross-flow turbines, it varies between 0.5 and 0.7 .

The generator efficiency $\eta_{\text {generator }}$ is usually more then 0.9 . The efficiency of the rest of the electrical system $\eta_{\text {el-system }}$ is usually more then 0.95 . This value can be lower if inverters or long transmitting power cables are used.

\section{B. Small Hydro Plants System}

A small hydro generating station can be described under three main headings: civil works, mechanical equipment, and electrical equipment. The final decision on the turbine, electrical equipment and dimensions of the civil works is done by the potential of the plant and the power required. The potential of hydropower depends on the head and the flow available in the river. Rivers can be classified into low head (less than $15 \mathrm{~m}$ ), medium head $(15$ to $100 \mathrm{~m})$ and high head (higher than $100 \mathrm{~m}$ ). As presented in Figure 1, the small hydropower systems include some essential components:

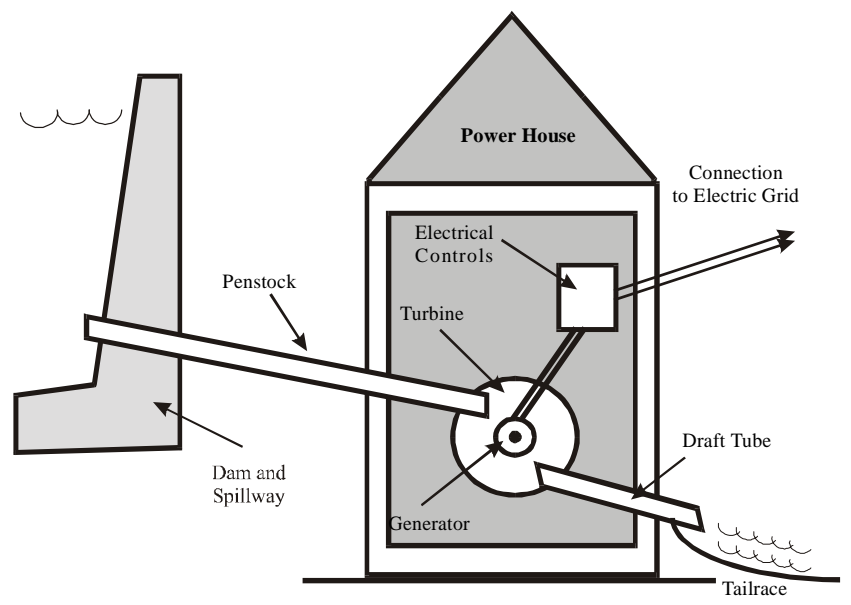

Fig. 1. General view of a small hydro system

1- diversion Structures: They are made to prevent the damage of overground structure from big boulders and flash flood of very high intensity.

2- water conductor: It is constructed to provide water in the initial reaches followed by conventional type of open channels.

3. penstock: conveys water under pressure the water to the powerhouse and can be made of steel, iron, fiberglass, plastics, concrete or wood.

4. tailrace: carries the water from the turbine exit back to the river.

5. generating plant and allied equipment: consists of all the mechanical and electrical equipment.
Generally, a small hydro plant is run-of-river: no water is stored. In order to reduce the construction cost, a low dam or diversion weir of the simplest construction are normally used.

Economics dictates the feasibility of an hydro plant. Generally, a hydro system requires substantial initial capital investments and low operating costs. It is considered that the location and site conditions determine $75 \%$ of the development cost. Only about $25 \%$ of the cost is relatively fixed, being the cost of manufacturing the electromechanical equipment.

The primary electrical and mechanical components of a small hydro plant are the turbine(s) and generator(s).

A hydraulic turbine is a rotating machine driven by water under pressure from a penstock or forebay. The energy in the flowing water is converted to mechanical energy by a revolving wheel fitted with blades, buckets, or vanes. The flow is directed at the wheel by a nozzle or an injector allowing the flow to be adapted to the mechanical power required by the electrical equipment being driven. There are two main categories of turbines, depending on which of two methods for extracting energy are used: impulse and reaction turbines. The choice depends on the head type of the river: for low to medium head applications, reaction type include Francis and fixed and variable pitch (Kaplan) propeller turbines are used; high head applications use generally impulse turbines.

In small hydro plants two types of generators can be used: asynchronous and synchronous machines. The asynchronous generator must normally be operated in conjunction with other generators or capacitors. With a capacity less than about $500 \mathrm{~kW}$, they are generally best suited for small hydro plants providing energy to a large existing electricity grid. Synchronous generator can be operated in isolation and they are best suited for isolated diesel-grid and stand-alone small hydro plants.

Besides the two primary electrical and mechanical components, a small hydro plant includes: speed increaser between turbine and the generator, ware shutoff valve for turbine, river by-pass gate and controls (if required), hydraulic control system for turbines and valves, electrical protection and control system, transformers, ventilation system, backup power supply, batteries, etc.

Building a small hydro plant suppose a specific steps to follow, from the calculation of electric power available on the site to the civil work and the legal and institutional problems Generally, the time of the preparatory stage is directly proportional with the complexity of the plant.

An evaluation on the environmental effects must be done stressing on the effect of the dam on fish, possibility of creating a breeding ground for diseases, flooding problems, etc. 
Assuming that the decision of building was made, the total cost is known, the location has been chosen, etc., the next step is to design and to effectively build the plant. Usually, people without much special training, using mostly local materials and skills can build a small hydro plant. The major steps in this process are described below.

1) the preparation of the budget and facilities schedule, the arranging financing are first the key steps.

2) the turbine(s), generator(s), batteries, pipe for the penstock, the inverter and any other items must be ordered. It is usually best to buy synchronous generators as part of a "package" consisting of generator, turbine and control system.

3) the delivery of the mechanical and electrical components can take some time. This will affect the total time spent for building. Meanwhile the dam, powerhouse, head trace, tailrace and other civil works can be built. The next step is to install the penstock and valves.

4) the final step is to test everything, first component by component, then, after the installation, the system as a whole.

\section{Environmental Impact}

Current hydropower technology, although essentially emission-free, can have undesirable environmental effects, such as fish injury and mortality from passage through turbines, as well as detrimental changes in the quality (dissolved gases) or downstream water. Advanced hydropower turbines technology minimize the adverse effects yet preserve the ability to generate electricity from an important renewable resource. Because physical or fluid forces cause this damage, improving passage conditions within the turbine may lower turbine passage losses. Another solution is the use of various forms of screening.

Small hydro power is in most cases "run-of-river". It means that any dam or barrage is generally quite small or in some cases it doesn't even exist, and no water is stored. Environmentally speaking, this is a big advantage compared with large scale hydro systems., no adverse effect on the local environment exists. Of course the main drawback is the low flow time.

As a conclusion, it is general admitted that from ecological point of view, the small hydro plants are welcome in the nature and they produce clean energy.

\section{Cost of a Small Hydro Plant}

Economics dictates the feasibility of hydropower installation even if all other factors are positive. Two principal economic characteristics of hydropower are high initial costs and low operating costs. In general, a hydropower system requires substantial initial capital investments to minimize operating costs. However, there is a point where excessively high capital costs will create the reverse effect of much higher operating costs. Each hydro site is unique, since about $75 \%$ of the development cost is determined by the location and site conditions. Only about $25 \%$ of the cost is relatively fixed, being the cost of manufacturing the electromechanical equipment.

To reduce initial costs, several cost-cutting steps can be taken:

1. maintain low administrative costs;

2. use local labor;

3. use local materials as much as possible;

4. build some of the equipment locally;

5. design an appropriate hydropower system (i.e., one that does not require high system efficiency, installation of a governor--a device used for maintaining uniform speed in a turbine, or recruitment of a full-time staff);

6. do not provide for a profit margin included in most costings for microhydropower installations;

7. minimize use of costly technical expertise and supervision.

Smaller hydro generators (200-500W) designed for battery charging tend to overcome the above two problems associated with larger $240 \mathrm{~V}$ type small hydro power. They generally weigh less than $25-40 \mathrm{~kg}$ and the penstock is usually lightweight poly pipe of $25-75 \mathrm{~mm}$ in diameter. The generating equipment for higher-head, lower flow installations are generally less expensive than lower-head, higher-flow plants. It is not necessarily the same for civil works components that are related much more to the local topography and physical nature of a site. Compare with solar systems, the battery used on a SHP can have a lower quality and a reduction of the size of $10 \%$. Batteries for SHP are not subjected to a deep cycling (charging - discharging cycle), and therefore automotive or truck batteries that are far cheaper and more readily available, should give 2-3 year of life in a SHP installation. Until recently, SHP battery chargers used a car alternator as a charger, which are relatively cheap.

An estimate cost of building the plant at the site and the annual cost of the plant (including loan payments, annual maintenance, and all other costs) will give an approximate cost per kWh produced by the hydro plant.

In order to have a complete image to the local cost of a small hydro power, let us assume a site built in Australia with on a low head site $(1.2 \mathrm{~m})$ but with high volume $(0.1$ to $\left.0.2 \mathrm{~m}^{3} / \mathrm{s}\right)$. The plant is equipped with a $240-\mathrm{Vac}$ alternator driven by a low head axial flow turbine. The $4 \mathrm{kVA}$ alternator delivers a constant output of $1.2 \mathrm{kVA}$ 
(relatively small), but enough for all household requirements. All the system is surveyed by a controller in order to maintain $50 \mathrm{~Hz}$ and $240 \mathrm{~V}$ and for protection. The minimal flow required running the turbine is $0.2 \mathrm{~m} / \mathrm{s}$. During low flow, a small battery bank and an inverter can be used.

TABLE III - SMALL HydRo InSTALLATION COSTS

\begin{tabular}{|l|l|l|l|}
\hline $\mathbf{Q}$ & Item & Cost (€) & \% \\
\hline 1 & concrete water tank & 4000 & 28 \\
\hline 1 & $\begin{array}{l}\text { 240 V pelton } \\
\text { wheel/alternator }\end{array}$ & 3000 & 21 \\
\hline 450 & $\begin{array}{l}\text { meters of } 80 \mathrm{~mm} \text { PVA } \\
\text { pipe }\end{array}$ & 1500 & 10 \\
\hline 2 & Macron 4 kVA alternators & 1300 & 9 \\
\hline 400 & meters of paired cable & 1200 & 8 \\
\hline 1 & $\begin{array}{l}\text { groundfoss centrifugal } \\
\text { pump }\end{array}$ & 1000 & 7 \\
\hline 1 & frequency controller & 1000 & 7 \\
\hline 1 & tower of power & 600 & 4 \\
\hline 1 & concrete weir & 500 & 3 \\
\hline 1 & $\begin{array}{l}12 \text { V pelton } \\
\text { wheel/alternator }\end{array}$ & 200 & 1 \\
\cline { 1 - 2 } Total & & $€ 14300$ & \multicolumn{2}{|l}{} \\
\cline { 1 - 3 } & &
\end{tabular}

The flow in the summer is less than the minimum required, so a turbine shutoff valve is essential. In this case, the duty cycle of the alternator-turbine is $80 \%$. For the flow rates plants, it is preferable the use of a crossflow turbine which can be throttled by either a pivoting guide-vane or a shutter arrangement across the water jet. This throttling ability, and easy of home manufacture, makes this turbine a first choice for many low head installations. A rough costing for the equipment is presented in Table III [5]. The cost of a comparable solar system would be 4.7 times more due to the high price of solar panels. The cost of a small hydro plant varies depending on what kind of equipment and how much material is used, and how much the civil work and other factors cost.

There are two extremes in calculating the total cost, depending of the way the plant is built. If the owner is able to build the structure, headrace, etc, using secondhand or recycled material, the cost would be very little. On the other hand, hiring a contractor to build the dam, canal, powerhouse, etc, and the use of new electromechanical components, the total cost will be relatively high. The electrical equipment such as alternators, batteries and rectifiers can be found in local shops and their cost can be found in catalogues. To the technological cost, maintenance and operation cost must be added. The cost of land acquisition and of the dam and reservoir construction (if it is the case) must be included in the total cost of power. If the construction costs are properly prorated to the non-power-producing utility of the unit, electricity can be sold very cheaply.

\section{Small Hydro Plants in Flanders}

In Flanders the power of hydro plant unit is of order of 10 to $100 \mathrm{~kW}$. These are machines with a limited dimension. For a turbine the diameter is less than 1 to $1.2 \mathrm{~m}$. There is no limit in the given power, if the head site is big enough, a turbine with a diameter of $1.2 \mathrm{~m}$ can produce till $500 \mathrm{~kW}$ without essential changes of technology. In Flanders the restoration of a large number of hydro sites is very reasonable, the most interesting sites being those with Francis turbines. Less appropriate would be the construction of new hydro sites, which are equipped with Kaplan turbines. Most of the existing hydro sites are rebuilt for historical reasons, generally being difficult to give them an energetical function.

An example is the restoration of the hydro site of Doren in Rotselaar (Molen van Doren in Rotselaar) by the company Ecowatt NV. The price of the restoration was very high, being about $250000 €$, which means a cost of $3375 € / \mathrm{kW}[6]$.

TABLE IV. Distribution of sites Vs the available power

\begin{tabular}{|l|l|}
\hline Available power & Number of sites \\
\hline$<5 \mathrm{~kW}$ & 189 \\
\hline $5-10 \mathrm{~kW}$ & 60 \\
\hline $10-15 \mathrm{~kW}$ & 19 \\
\hline $15-40 \mathrm{~kW}$ & 34 \\
\hline$>40 \mathrm{~kW}$ & 18 \\
\hline
\end{tabular}

Conform to a study from 1996, in Flanders are two main categories of hydro sites: classical small hydro power and locks in canals. The potential of both categories is 4.2 MW and respectively $12.5 \mathrm{MW}$. Flanders, including Brussels, counts about 300 sites ready for restoration. Most of these sites have a head between 1 and $3 \mathrm{~m}$, only 3 having a head higher than $5 \mathrm{~m}$. Table IV presents a distribution of the available power. Most of the installations have an extremely small power (less than 5 $\mathrm{kW}$ ).

TABLE V. shows the total distribution of the available power $(\mathrm{kW})$ for small hydro power in Flanders.

TABLE V. Total power distribution $(\mathrm{kW})$ for small hydro power in Flanders

\begin{tabular}{|l|l|}
\hline Region & Available power [kW] \\
\hline Antwerpen & 360 \\
\hline Limburg & 1126 \\
\hline Oost-Vlaanderen & 361 \\
\hline Vlaams-Brabant & 1877 \\
\hline West-Vlaanderen & 362 \\
\hline Brussels Gewest & 75 \\
\hline Total & $\mathbf{4 1 8 1}$ \\
\hline
\end{tabular}

There in total 38 locks in Flanders, most of them with head between 1 and $3 \mathrm{~m}$. Most of the sites have a power between $100 \mathrm{~kW}$ and $500 \mathrm{~kW}$. The total power for Flanders is about $12.5 \mathrm{MW}$. The distribution of the power $(\mathrm{kW})$ for locks in Flanders is shown in TABLE VI. 
TABLE VI. Total power distribution $(\mathrm{kW})$ for locks in Flanders

\begin{tabular}{|l|l|}
\hline Region & Available power $[\mathbf{k W}]$ \\
\hline Antwerpen & 4725 \\
\hline Limburg & 3796 \\
\hline Oost-Vlaanderen & 2212 \\
\hline Vlaams-Brabant & 362 \\
\hline West-Vlaanderen & 1395 \\
\hline Total & $\mathbf{1 2 4 6 0}$ \\
\hline
\end{tabular}

In Flanders, the possibilities for restoration of small hydro plants are bigger than the construction of new sites. There many hydro plants with primitive water wheels (for example Zuppinger, Sagebien)., making the restoration difficult.

An example of restoration is the hydro plant Dijlemolens in Leuven, by Ecowatt. The speed is approximately 10 $\mathrm{rpm}$, with a given power of $16 \mathrm{~kW}$. An evaluation of the flow and the head turned out that the turbine has been wrongly dimensioned and the machine had to be taken out of operation. Ecowatt had to adapt the dimensions of the machine and finally to reinstall it. Another interesting example is the Rotselaar site. This site equipped with a Francis turbine, has a head of $2.3 \mathrm{~m}$ and a flow of 5.2 $\mathrm{m}^{3} / \mathrm{s}$, providing a theoretically available power of 118.2 $\mathrm{kW}$. The turbine with a diameter of $2.8 \mathrm{~m}$ provides a power of $75 \mathrm{~kW}$. The Kaplan turbine installed in the "Grote Molen" of Hoegaarden, has adjustable blades, so that the variable flow can be optimally used (from 1.8 $\mathrm{m}^{3} / \mathrm{s}$ to $0.6 \mathrm{~m}^{3} / \mathrm{s}$ ). The site is provided with two automatically slot valves, creating the required head (about $2.5 \mathrm{~m}$ ) in order to assure a flow of approximately $1.2 \mathrm{~m}^{3} / \mathrm{s}$.

\section{Conclusion}

After reviewing the tendencies of the energy market for the next century, Small and Micro-Power Systems are presented. The decision to build a hydro plant must be based on studies about the site potential, economical potential, environmental impact and technological aspects. This paper presents the literature study of the advantages and drawbacks of Small and Micro Hydro Plants. In the last years, special attention was paid to the wind and solar power.
A comparison with other renewable is therefore very important. It is not only a "technical" study of renewable systems with an emphasis on hydro plants, but it presents also the new technology in an easy way in order to familiarize a non-technical investor with the main characteristics and costs. A brief presentation of existing hydro park in Flanders (Belgium) is discussed.

\section{Acknowledgement}

The authors are grateful to the Belgian 'Fonds voor Wetenschappelijk Onderzoek Vlaanderen' for their financial support of this work. C. Dragu is a doctoral research student assistant at ELECTA - K.U.Leuven; J. Soens is a doctoral research assistant of the F.W.O.Vlaanderen.

\section{References}

[1] DRI/McGraw-Hill, The Future of the Electric Power Industry. Volume I: Western Europe (Lexington, MA, November 1995), p. 186.

[2] WEFA Group, World Power Service: Western European Report (London, UK, November 1995)

[3] Peter Fraenkel, Flowing too slowly?, Renewable Energy World, March 99, pp.51-54

[4] Christofer S. Weaver, P.E., Understanding MicroHydroelectric Generation, ISBN: 0-8661-218-2 [C]1985, Volunteers in Technical Assistance, vita@vita.org.

[5] John Hermans, 240 vac Direct Drive Hydro, Home power \#65, June/July 1998, pp. 36-41

[6] E. Dick, D. Vansintjan, Het potentieel van waterkracht in Vlaanderen, Mogelijkheden voor kleinschalige waterkracht in Vlaanderen, Rupelmonde, Belgium, 22 juni 1999 